\title{
INTRA-ASIAN FDI FLOWS: TRENDS, PATTERNS AND DETERMINANTS
}

\author{
by
}

\author{
Rabin Hattari ${ }^{\star}$ and Ramkishen S. Rajan ${ }^{\star \star}$
}

April 2006 (Preliminary; not to be quoted)

* International Monetary Fund (IMF) and Department of Economics, George Mason University, VA. E-mail: rhattari@gmu.edu .

** School of Public Policy, George Mason University, VA. E-mail: rrajan1@gmu.edu .

Research assistance by Nicola Virgill is gratefully acknowledged. The usual disclaimer applies. 


\section{Intra-Asian FDI Flows: Trends, Patterns and Determinants}

\section{Introduction}

Global economic expansion has been increasingly fuelled by the rapid growth in and transformation of China and India along with the revitalization of Japan and the recovery of the emerging economies in Southeast Asia and South Korea from the crisis of 1997-98. While Asia has been integrating rapidly with the global economy, there is clear evidence of closer de facto intra-Asian integration as well. Although the focus of a great deal of scholarly work thus far has been on intra-Asian trade integration and business cycle synchronizations, there are signs that intra-Asian capital flows have also been intensifying (see Kharas et al., 2006 in the case of East Asia). Of particular interest in this regard has been the rise of intra-regional FDI flows.

Certainly, investments in the region by Japanese multinationals are not something new, having been fuelled partly by the Plaza Accord of 1984-85. This was followed by intra-regional investments by companies from high income economies such as Hong Kong, Korea, Singapore and Taiwan. However, an interesting phenomenon in recent times (since early 2000) has been the rise of outward investments by Chinese and Indian companies. Anecdotal evidence of this phenomenon abounds, with many multinationals from China and India being in particularly expansive mood. In other words, intra-Asian FDI flows are no longer a North-South phenomenon but increasingly a South-South one as well.

The phenomenon of South-South FDI flows, particularly those arising from multinationals from China and India, has generated significant interest from policymakers, academia and the popular press in recent times. ${ }^{1}$ Available data from the Word Bank indicates South-South FDI to have increased almost three-fold (from \$14 billion in 1995 to

1 South-South FDI by small and medium size enterprises (SMEs) is also an important phenomenon, particularly in extractive industries and infrastructure (World Bank, 2006). Aykut and Goldstein (2006) briefly discuss the implications of South-South FDI flows. 
$\$ 47$ billion in 2003), and accounts for almost 37 percent of total FDI flows to developing countries, up from 15 percent in 1995 (Table 1). Of the top hundred multinationals from developing economies that have the potential to become global players, 65 are from Mainland China and India (BCG, 2006; also see Aguiar et al., 2006). The Chinese government has stated its intention to help develop 30-50 "national champions" that can "go global" by 2010 (Accenture, 2006, Sauvant, 2006 and Wu, 2005). Given this, along with aggressive overseas acquisition plans by cash-rich and highly confident firms from India, Hong Kong, South Korea and Taiwan, as well as by national holdings companies in Singapore (Temasek Holdings) and Malaysia (Khazana National Berhad), outward investments by Asian companies are set to rise further both intra-regionally and globally. According to some estimates, intra-Asian FDI flows in 2004 have accounted for about 40 percent of Asia's total FDI inflows in 2004 (Kwan and Cheung, 2006; also see UNCTAD, 2006, Chapter 2).

What has been behind the rise in outward FDI from developing Asia in general? First, and most commonly recognized is the strategic goal of China and India, in particular, in ensuring that they have sufficient supplies of key resources, such as oil, gas and steel, needed to fuel domestic growth. The desire for energy security is key to China's policy and it appears willing to pay a hefty premium to fulfill this objective. Second, is the aspiration by Asian companies to buy brand names, technology, processes, management know-how and marketing and distribution networks. This was the motivation behind Lenovo's purchase of IBM's personal computer, thus propelling Lenovo to become the world's third-largest computer maker, after Dell and HewlettPackard (HP). In addition to purchasing advanced technology and brand names, the desire to cut out middlemen and thus increase profit margins will inevitably imply that more cash-rich Asian companies will be looking to enter the Western markets, particularly the US. Third is the desire by Asian companies to solidify existing markets or seek new ones. Such market-seeking investments will grow in importance as Asian companies are 
beginning to face intense foreign competition at home and are looking to expand overseas market shares. Fourth, like Japanese firms before them, many firms from Asian NIEs have been investing in China, Vietnam and other regional economies as a means of maintaining competitiveness (i.e. so called "efficiency seeking investments).

Apart from access to natural resources and a desire to enhance efficiency or augment existing assets and remain competitive, a rather tangential rationale for - or rather, result of - overseas acquisitions and concomitant capital outflows has been an easing of exchange rate pressures on Asian currencies, thus reducing the need for reserve buildup and having to manage its inflationary consequences (Rajan and Rongala, 2007, Chapter 1). There may be other motivations as well for Asia's external thrust (e.g. reduce political risk at home, tariff-jumping, geopolitical, etc). Policy makers in many Asian economies like China and India have been particularly keen in promoting an internationalization thrust and have facilitated outward FDI via gradual liberalization of rules governing capital account outflows and in many cases, providing a financing mechanism to domestic firms looking to invest abroad. ${ }^{2}$

While the above drivers for outward FDI are clearly not exhaustive, this paper investigates trends, patterns and determinants of intra-Asian FDI flows in more detail. Section 2 outlines definitions of FDI and various data sources. As will be discussed, the primary data source used is the UNCTAD database. Section 3 discusses broad patterns and trends in intra-Asia FDI flows using bilateral FDI flows over the period 1997 to 2005. Section 4 develops a simple empirical model to consider the main economic and institutional determinants of intra-Asian FDI flows. To our knowledge, our study is one of the few to examine the determinants on intra-bilateral FDI between Asian countries using a panel data. The advantage of our study is that we can exclude all the time-invariant analysis that are specific to a country pair, such as bilateral distance and common

\footnotetext{
${ }^{2}$ For instance, Gopinath (2007) discusses the steps taken by the Indian government to facilitate outward FDI. Sauvant (2005) describes steps taken by both India and China to promote outward FDI from that country.
} 
language. The final section offers a few concluding remarks. An Annex provides more information on the data used for the regression analysis in Section 4.

\section{Definitions and Data Sources}

According to the IMF Balance of Payments Manual (5 $5^{\text {th }}$ Edition, 1993):

FDI refers to an investment made to acquire lasting interest in enterprises operating outside of the economy of the investor. Further, in cases of FDI, the investor's purpose is to gain an effective voice in the management of the enterprise. The foreign entity or group of associated entities that makes the investment is termed the 'direct investor'. The unincorporated or incorporated enterprise-a branch or subsidiary, respectively, in which direct investment is made-is referred to as a 'direct investment enterprise'.

At an operational level, FDI commonly bears three broad characteristics. First, it refers to a source of external financing rather than necessarily net physical investment or real activity per se. $^{3}$ Second, as a matter of convention FDI involves a 10 percent threshold value of ownership. Third, FDI consists of both the initial transaction that creates (or liquidates) investments as well as subsequent transactions between the direct investor and the direct investment enterprises aimed at maintaining, expanding or reducing investments. More specifically, FDI is defined as consisting of three broad aspects, viz. new foreign equity flows (which is the foreign investor's purchases of shares in an enterprise in a foreign country), intra-company debt transactions (which refer to short-term or long-term borrowing and lending of funds including debt securities and trade credits between the parent company and its affiliates) and reinvested earnings (which comprises the investor's share of earnings not distributed as dividends by affiliates or remitted to the home country, but rather reinvested in the host country). New equity flows

\footnotetext{
${ }^{3} \mathrm{~A}$ priori it is unclear whether FDI over or under-estimates actual real economic activity as this requires consideration of the impact of FDI on existing domestic investment, extent of technology transfer, employment creation, and the like. The impact on FDI on net capital flows is also uncertain as greater FDI inflows could encourage portfolio and bank flows, while simultaneously, M\&A inflows could lead to the previous local owners choosing to invest some of their returns overseas, leading to capital outflows. The nexus between FDI and other sources of financing is explored in Rajan (2005).
} 
could either be in the form of M\&A of existing local enterprises or Greenfield investments (i.e. establishment of new production facilities).

While this is the most common definition as set out by the OECD Benchmark Definition of FDI ( $3^{\text {rd }}$ Edition, 1996) and IMF Balance of Payments Manual ( $5^{T H}$ Edition, 1993), it is not always adhered to by all countries systematically. ${ }^{4}$ In fact, reported outward FDI often tends to be under-reported as it tends to exclude the financing and reinvested components. For emerging economies, the two most comprehensive databases on FDI inflows and outflows are IMF-BoP Manual and UNCTAD (see Duce, 2003 for a comparison of the two sources). Neither source divides FDI into M\&A versus Greenfield investments. ${ }^{5}$ While most M\&A statistics are compiled by commercial data sources, they tend to include announced rather than actual financial flows and some of the announced flows may not even include activities considered to be FDI (as defined above). More to the point, announced flows often includes funding of capital via equity from local minority share-holders or local/international borrowing (as opposed to funds from the parent or sister companies) and are thus of limited use for the purposes at hand. ${ }^{6}$

UNCTAD by far has the most complete FDI database, and unlike the IMF-BOP data, it compiles data on bilateral FDI flows - both inflows and outflows. ${ }^{7}$ The UNCTAD

\footnotetext{
${ }^{4}$ In addition, not all countries use the 10 percent criterion for defining FDI. For a detailed overview of the FDI definitions and coverage in selected developing and developed countries, see IMF (2003). Also see Table 2 and discussion in Aykut and Ratha (2004) and Duce (2003).

${ }^{5}$ See UNCTAD (2006, pp.15-21) for a discussion of Greenfield versus M\&As. In the past three years, cross-border merger and acquisition (M\&A) have been experiencing a surge. UNCTAD reports that in 2005 both value and the number of cross-border M\&A rose to US\$716 billion and to 6,134 which are increased of 88 percent and 20 percent, respectively. Bloomberg, Thomson Financial, Dealogic and OCO Consulting's LOCO Database record all M\&A deals that are reported by news and media in their database. UNCTAD M\&A database is drawn out from Thomson Financial.

${ }^{6}$ Globerman and Shapiro (2005) find many common determinants in both modes of FDI.

${ }^{7}$ UNCTAD FDI database contains 1.1 million pieces of data on detailed geographical and industry breakdown of FDI flows and stocks.
} 
data are on a net basis (capital transactions credits less debits between direct investors and their foreign affiliates). The main sources for UNCTAD's FDI flows are national authorities (central banks or statistical office). These data are further complemented by the data obtained from other international organizations such as the IMF, the World Bank (World Development Indicators), the Organisation for Economic Co-operation and Development (OECD), the Economic Commission for Europe (ECE) and the Economic Commission for Latin America and the Caribbean (ECLAC), and UNCTAD's own estimates. $^{8}$

\section{The Extent of Intra-Asian FDI Flows: Trends and Patterns}

One could undertake data analysis using either stocks (referred to as International Investment Position or IIP) or flows (i.e. financial account transactions). While much empirical analysis to date has been using the former, changes in stocks could arise either because of net new flows or because of valuation changes and other adjustments (like write-offs, reclassifications etc). To abstract from these valuation and other changes we consider only data on flows of outward FDI (net decreases in assets or when a foreign country invests in the country in question) and inward FDI (net increases in liabilities or when the home country invests abroad).

We focus on selected South, Southeast and East Asian developing economies. The economies included in our sample are Bangladesh, Mainland China, Hong Kong, India, Indonesia, Malaysia, Pakistan, the Philippines, Singapore, Taiwan, Thailand, South Korea, and Vietnam. Thus, apart from excluding West Asia and some smaller Asian

\footnotetext{
${ }^{8}$ The process of data collection for UNCTAD FDI/TNC databank is complicated and requires using data from different databases or own estimation. For instance, UNCTAD uses data from the World Bank's World Development Indicators for economies that lack data from national official sources or the IMF or for which available data do not cover the entire period. For developing countries in which their FDI flows data are unavailable in either IMF or World Bank, UNCTAD employed regional cooperation databases, such as ECLAC, and ECE, to fill in the missing data. For OECD countries, data on the FDI outflows from OECD database are used as proxy for FDI inflows. For those economies for which data were not available from either of the above-mentioned sources or only partial were available, UNCTAD uses its own estimates.
} 
economies in South and East Asia, we exclude Japan but follow UNCTAD in defining the NIEs like Hong Kong, Singapore, South Korea and Taiwan as "developing".

\subsection{Aggregate Inflows to and Outflows from Developing Asia}

Table 2 reveals relative shares of global FDI inflows and outflows. As is apparent, the Triad (the EU, Japan and the United States) continue to dominate both as sources and destinations of FDI in terms of both stocks and flows. However, it is interesting to note that in 2003-2005 the Triad's share of FDI flows declined to a low of below 60 percent compared to about 80 percent on average between 1978 and 1990, while that to developing economies rose to a corresponding high of 40 percent, over half of which was destined to Asia. With regard to outflows, the UNCTAD (2006) has noted the following:

Developing countries' have gained in importance as recipients of FDI in terms of both inward flows and stocks. Their share in total world inflows rose from an average of $20 \%$ in $1978-1980$ to an average of $35 \%$ in 2003 2005, though the performance of the different regional groups was uneven...The share of Asia and Oceania, particularly South, East and South-East Asia, increased rapidly - driven partly by flows to China which appeared on the FDI scene only in the late 1970s - until the end of the 1990 s and then slowed down somewhat in the early 2000s...Data on FDI outflows from developing countries point to the increasing dynamism of this group of countries as sources of FDI. Their share in global outward FDI stock has fluctuated between $8 \%$ and $15 \%$ over the past 25 years, while their share in outflows points to a clearly increasing trend. Negligible or small until the mid-1980s, such flows from developing countries amounted to $\$ 117$ billion, or about $15 \%$ of world outflows in 2005 . Their FDI outward stock increased from $\$ 72$ billion in 1980 to $\$ 149$ billion in 1990 and to more than $\$ 1$ trillion in 2005 . More importantly, a number of developing countries have emerged as significant sources of FDI in other developing countries, and their investments are now considered a new and important source of capital and production know-how, especially for host countries in developing regions (p.6).

Table 3 focuses specifically on FDI inflows and outflows of selected Asian developing economies between 1990 and 2005. During 1990 to 1996, FDI inflows to Asia grew at an average annual rate of just over US\$50 billion, while outflows grew at a rate of US $\$ 30$ billion during the same period. Buoyant global economic conditions and the liberalization of most of the Asian economies in the early 1990s led to an influx of inflows 
to the region. In contrast, during 1997 to 2005 average annual FDI growth in outflows from Asia outpaced inflows to Asia (US\$22 billion on average compared with US\$50 billion annually). The fact that outflows outpaced inflows reveals that Asian countries are investing outside their region. ${ }^{9}$ Further, FDI outflows and inflows for most countries during the sub-periods 1990 to 1996 and 1997 to 2005 are positively correlated, with the exceptions of Korea (first sub-period), the Philippines (second sub-period), and Bangladesh (entire period). The correlations in Greater China (Mainland plus Hong Kong) and India are particularly high, suggesting that periods of economic liberalization have been characterized by simultaneous rises in both FDI inflows as well as outflows (Table 4).

Interestingly, the two countries with the highest magnitudes of inflows and outflows are Mainland China and Hong Kong (see Table 3 again). In both of our sample periods 1990 to 1996 and 1997 to 2005, China has been the single largest destination of FDI, contributing between 38 and 40 percent of inflows to developing Asia during the last 15 years. More specifically, for the period 1990 to 1996, the average FDI inflows to Mainland China was around US\$20 billion, while for the second sub-period, 1997 to 2005, the average FDI inflows to Mainland China crossed US\$ 50 billion. With regard to outflows, Hong Kong is clearly the largest source of FDI outflows from Asia. FDI outflows from Hong Kong averaged just under US\$15 billion annually in the first sub-period and over US\$ 25 billion in the second sub-period. ${ }^{10}$ As will be noted below, a large part of outflows from Hong Kong is bound for Mainland China, some of which is due to roundtripping from the Mainland to begin with. This round-tripping significantly inflates the

\footnotetext{
${ }^{9}$ The volatility (measured by standard deviations) of inflows (25.5) is much higher than outflows (108.8). This indicates more fluctuations in outflows.

${ }^{10}$ Chen and Lin (2006) discuss patterns and determinants of FDI outflows from Hong Kong, SAR and Mainland China.
} 
amount of outward FDI from the Mainland which itself experienced a spurt between 1990 and 2005 (UNCTAD, 2006, p.12). ${ }^{11}$

Referring to Table 3 on flows and Table 5 on stocks, the significant difference between outflows from Hong Kong with the rest of our sample countries is apparent. Hong Kong's outflows are at an altogether different level than any other regional economy. Excluding Hong Kong from the analyses, the picture is more even across our sample countries. It is apparent that the three NIEs of Singapore, South Korea and Taiwan have consistently remained among the top developing economy sources of FDI over the last two decades. Malaysia (a near-NIE) is also notable for the size of their outward FDI flows, particularly since the 1990s. Indonesia remains an important source of FDI, while more aggressive internationalization strategies by Indian companies has seen it rise in the rankings from 39 in 1990 to top 20 by $2005 .^{12}$ These 7 economies constitute the bulk of outward FDI from Asia. Table 6 summarizes some key facts of the stock of outward FDI from these seven economies as well as two other middle income economies, Thailand and the Philippines as of 2005.

\subsection{Intraregional Asian FDI Flows}

Having considered broad country aggregate outflows and inflows to and from Asia, we analyze bilateral FDI between selected Asian countries. This exercise is far from straightforward. As mentioned in the last section, UNCTAD data on inflows and outflows do not match (also see UNCTAD, 2006, Chapter 3). It is apparent that UNCTAD FDI outflows data from donor countries are incomplete for many countries. While some donor countries (Malaysia and Thailand) have relatively complete outflows data, others either

${ }^{11}$ Estimates put round-tripping at between 25 and 50 percent of total FDI flows from Hong Kong, SAR to Mainland China.

12 Anecdotal evidence suggests that Indian companies have been particularly aggressive in investing overseas in 2006-2007. 
have incomplete data (India and Singapore), or no data all (Mainland China). In contrast, FDI inflow data reported in host economy are more complete and data are available for all developing Asian economies under consideration here (see Box 1). In view of this we draw inferences on FDI outflows by examining data based on FDI inflows to the host economy (i.e. we focus on the sources of inflows rather than destination of outflows). To keep the analysis manageable we examine data for the averages of 1997 to 2000 , and 2001 to 2005 rather than on an annual basis. ${ }^{13}$

FDI inflows between Asian countries accounts for almost half of all FDI inflows to the region (Table 7) and is particularly pronounced between and within East Asian economies and South-East Asia economies. This is apparent from Table 8 which highlights that the bilateral flows between East Asian countries are the highest in Asia with an average of US\$28 billion for the period of 1997 to 2005. According to Table 9, the average of FDI flows from Hong Kong to China and vice versa from 1997 to 2005 has averaged around US\$24 billion and accounts for almost of 40 percent of intra-Asia. Apart from intra-East Asian FDI flows, bilateral flows between East and South-East Asia are also fairly large, averaging US\$1.3 billion in the period 1997 to 2005. Almost three-fifths of flows from East Asia to South-East Asia have been destined for the relatively higherincome South-East economies, viz. Singapore, Malaysia, Philippines and Thailand. The city state of Singapore has attracted about half of all of East Asian FDI destined for South-East Asia.

Tables 7 - 9 highlight a few other important characteristics of intra-Asian FDI flows. First, the leading investors from the region has stayed the same between 1997 to 2006, with Hong Kong as the leading investor, followed by Singapore, Taiwan, Korea, China, and Malaysia, in that order. Second, intra South-East Asia investment accounted for 6.7 percent of cumulative FDI flows in Asia between 1997 and 2005. Comparing the

\footnotetext{
${ }^{13}$ It is instructive to note that the top destinations of FDI using data based on FDI inflow data in host economy, and FDI outflow data from donor country have roughly stayed the same.
} 
two sample periods, intra South-East Asia's investment share of cumulative FDI flows in Asia increased between the two periods from 4.5 percent to 7.5 percent, with Singapore as the leading investor in both periods. Third, intraregional FDI flows between South Asia have been less significant in comparison to other subregions, and those between SouthEast Asia / East Asia and South Asia have not been as significant as those between East Asia and South-East Asia. However, it is noticeable that both intra-South Asian FDI as well as FDI from South Asia to South-East Asia have increased relatively markedly between 2001 and 2005. Fourth, in reference to South Asian investments in South-East Asia, Malaysia appears to be South Asia's preferred destination within Asia, and India is the leading South Asian investor with much of the FDI sources from Malaysia and Singapore. FDI between East Asia and South Asia remains low and stagnant. Recent interest expressed by Japanese, Korean and Taiwanese firms in the booming Indian economy may alter this, though that remains to be seen. ${ }^{14}$

\section{Determinants of FDI Outflows from Asia}

The previous section has highlighted the rise in FDI outflows from developing countries and more specifically, the intensification of intraregional FDI flows. But what explains the rise of intraregional FDI flows in Asia? This section undertakes a simple empirical investigation of some of the possible determinants behind the greater FDI outflows from Asia to the rest of the region.

\subsection{Model}

Following the framework by Lipsey (1999) there have been a vast number of studies on the determinants of FDI flows at both an individual country level and on a

${ }^{14}$ There appears to be some desire to diversify export market platforms from China although it is unclear whether this will lead to a shift of some FDI from Korea, Japan and Taiwan to India or to developing Southeast Asian economies such as Indonesia, Thailand, Vietnam, Philippines, Malaysia, etc. 
cross country level. ${ }^{15}$ By and large these studies have found market size, rate of income growth, and distance as important determinants in the choice of location of direct investment's donor countries. Some studies also include the bilateral exchange rate as an independent variable. In addition to these common macroeconomic variables it is often noted that FDI tends to occur close to their home country. In view of this we augmented the basic equation with common language, distance and shared land borders. ${ }^{16}$

The basic model to be estimated is outlined below:

$$
\begin{aligned}
& \ln \left(F D I_{i j t}\right)=\beta_{0}+\beta_{1} \ln \left(G D P_{j t} * G D P_{i t}\right)+\beta_{2} \ln \left(\text { Growth }_{i t} * \text { Growth }_{j t}\right)+\beta_{3} \ln \left(E X C B_{i j t}\right) \\
& +\beta_{4} L A N D_{i j}+\beta_{5} L A N G_{i j}+\beta_{6} \ln \left(D I S T_{i j}\right)+\varphi_{i j}+\varepsilon_{i j t}
\end{aligned}
$$

where: $F D I_{i j t}$ is the FDI outflow from source country (i) to host country (j) in time (t); $G D P_{i t}$ and $G D P_{j t}$ are real GDP for the source country (i) and the host country (j) in time (t); Growth ${ }_{i t}$ and Growth $_{j t}$ are real growth rates in the source and destination countries; $E X C B_{i j t}$ is the nominal bilateral exchange rate of the source country (i) to host country (j) currency at time (t). $L A N D_{i j}$ is a dummy variable for share of land border between host and source countries; $L A N G_{i j}$ is a dummy variable for common official language between host and source countries; and, $D I S T_{i j}$ is a geographical distance between host and source countries. $\varphi_{i j t}$ captures all unobserved, time-constant country-pair specific factors that affect FDI outflows (such as institutional type variables); hence their inclusion avoids omitted variable bias. $\mathcal{E}_{i j t}$ is the idiosyncratic error or time-varying error.

We expect the coefficients of the real GDP of the source and destination countries -- which are proxies for market size -- to be positive. The intuition behind this is that a

\footnotetext{
${ }^{15}$ Most recently the Lipsey model was applied by Lee (2002) to Korea's outwards investments to 102 host countries in the 1990s.

${ }^{16}$ Also see Hejazi (2005) who examined 28 OECD countries using data for selected years between 1980 and 1998 and included the usual macro variables in the Lipsey model as well as exchange rate, common language, shared border and regional dummies.
} 
country is more likely to invest in larger countries where they can diversify their portfolios. Real GDP can also be a proxy of masses which are important in gravity models. ${ }^{17}$ The growth of real GDP ought also to have a positive impact on bilateral FDI flows as it accounts for the dynamism of both the source and host economies. The bilateral exchange rate should have a negative sign as a depreciated exchange rate in the destination countries should raise FDI outflows from source countries (due to the wealth effects and pro-competitiveness effects). Common language should positively impact bilateral FDI flows. The share of land border should also have a positive sign, while the sign for distance from donor to host country should be negative, as a longer distance makes a foreign operation more difficult and expensive to supervise and might therefore discourage FDI. ${ }^{18}$

Chantasasawat (2004), Frankel and Wei (1996), Razin et al (2003), and others have found that policy and institutional variables impact FDI flows, while Aykut and Goldstein (2006) and World Bank (2006) have noted that investors tend to go to a country or region where they have acquired a certain familiarity via intensified trade links and have close language and cultural ties. ${ }^{19}$ In view of this we also re-estimated the equation by augmenting it with a set of institutional and policy related variables. To this end we include various sub-indices of the KOF-Index globalization as control variables. We use

\footnotetext{
${ }^{17}$ In physics, the law of gravity states that the force of gravity between two objects is proportional to the product of the masses of the two objects divided by the square of the distance between them. Most gravity models in bilateral trade and FDI have replaced the force of gravity with the value of bilateral trade or direct investments and the masses with the source and destination countries' GDP.

${ }^{18}$ However, if the foreign firm is looking to service the destination country's market, a longer distance also makes exporting from donor countries more expensive, and might therefore make local production more desirable and encourage investment. This argument is not unlike the tariffjumping one.

${ }^{19}$ Similarly, micro-level data indicates most ASEAN MNCs tried to minimize their operational costs by taking advantage of cheap labor operations and market access in their neighboring countries where cultural and language problems are mitigated (Hiratsuka, 2006).
} 
five sub-indices of KOF-Index globalization which measure the degree economic, social and political openness of the source and destination countries' (discussed below).

Equation (1) is augmented as follows:

$$
\begin{aligned}
& \ln \left(F D I_{i j t}\right)=\beta_{0}+\beta_{1} \ln \left(G D P_{j t} * G D P_{i t}\right)+\beta_{2} \ln \left(\text { Growth }_{i t} * \text { Growth }_{j t}\right)+\beta_{3} \ln \left(E X C B_{i j t}\right) \\
& +\beta_{4} L A N D_{i j}+\beta_{5} L A N G_{i j}+\beta_{6} \ln \left(D I S T_{i j}\right)+\beta_{7} \ln \left(K A P 1_{i t}+K A P 1_{j t}\right)+\beta_{8} \ln \left(S O C 1_{i t}+S O C 1_{j t}\right) \\
& +\beta_{9} \ln \left(S O C 2_{i t}+S O C 2_{j t}\right)+\beta_{10} \ln \left(S O C 3_{i t}+S O C 3_{j t}\right)+\beta_{11} \ln \left(P O L_{i t}+P O L_{j t}\right)+\varphi_{i j}+\varepsilon_{i j t}
\end{aligned}
$$

The KOF sub-indices on globalization are as follows. KAP1 is a sub-index on restrictions on trade and capital flows in the home and host countries. ${ }^{20}$ The level of restrictions on trade and capital should have a negative sign since FDI generally flows into countries that have lower trade and capital account restrictions. ${ }^{21}$ SOC1, SOC2, SOC 3 are sub-indices that capture the levels of personal contacts of a country, the depth of information flows of a country, and the level of cultural proximity of a country. ${ }^{22}$ Direct interactions among people or personal contacts, information flows, and similarity in cultures should all have a positive sign for obvious reasons. The final sub-index, $P O L$ measures the level of political globalization of a country. A country that is politically close to other country and/or is more involved in world politics, i.e. it has a high degree of political globalization, ought a priori to have a higher level of FDI inflows.

\subsection{Data, Methodology and Results}

Tables A1 and A2 summarize the data sources to be used. The FDI data are based on the UNCTAD FDI/TNC database. Real GDP in US dollar and real GDP per capita (base year 2000) are taken from World Bank's World Development Indicator

\footnotetext{
20 The KOF also includes a sub-index on actual economic flows such as trade, FDI and portfolio flows coming into the host countries. We exclude this in view of the fact that our dependent variable is measuring FDI flows per se.

${ }^{21}$ Of course, the exception would be tariff-jumping FDI.

${ }^{22}$ For more information, please refer to KOF-Index at http://globalization.kof.ethz.ch/.
} 
database. Exchange rates (average) are taken from the IMF's World Economic Outlook database. The subcomponents of KOF-Index of globalization are described in Box 2 . Data on the share of border land and common official language are from the CEPII. ${ }^{23}$

Before we begin our empirical analysis it is worth emphasizing that although we have 15 countries in the sample and potentially $14 \times 13=182$ source-host pairs, there are in actuality only 140 source-host pairs (14 donor countries and 10 host countries), i.e. not every country receives FDI from others. ${ }^{24}$ Our dataset is a panel dataset where we have 170 source-destination pairs, from 1990 to 2004, for a total of $170 \times 15$ observations.

We ran two separate regressions on each of the equations. The empirical results for the four sets of estimates are summarized in Table 10. Regression 1, which excludes the country-pair dummies, concurs with earlier findings based on cross-sectional data (for instance, Lipsey, 1999 and Lee, 2003). The result also confirms that common official language and share of land border, in addition to source and the host countries' market size variables, real growth, and distance, are important determinants for FDI outflows. ${ }^{25}$

We next employed a country-pair fixed effect in Regression 2. We started our analysis by pairing each source and destination countries as groups. Our methodology of employing a country-pair fixed effect is different from previous studies on direct investments in Asia which mostly relies on country or cross-section analyses. To our knowledge, our study is one of the few to examine the determinants on intra-bilateral FDI between Asian countries using a panel data. The advantage of our study is that we can exclude all the time-invariant analysis that are specific to a country pair, such as bilateral distance and common language. In this way, an Asian country that has traditionally

${ }^{23}$ http://www.cepii.fr/

${ }^{24}$ Missing data accounts for almost 48 percent and disinvestment accounts to 2 percent of our data set. To treat these missing variables and disinvestment, we replaced them with one. This will make them turn to zeros when we take their logs in our empirical analysis.

25 The findings broadly concur with the observations made by Hiratsuka (2006) on ASEAN countries. 
invested directly in another Asian country will affect the coefficients of market size, growth, and bilateral exchange rate. Regression 2 shows the result of our country-pair fixed effects. Similar to result in Regression 1, the major macroeconomic variables (market size, growth, and bilateral exchange rates) are significant with correct signs. The country-pair fixed effect clearly emphasizes the effects of bilateral exchange rate on FDI outflows unlike Regression 1 which finds no effect.

Next, we analyzed the effects of globalization to our dataset. Regression 3 is a pooled regression analysis with the addition of $6 \mathrm{KOF}$ sub-indices. The result indicates that with the exception of the political openness index, the other 4 components of the KOF subcomponents of economic globalization are the correct sign. The measure of trade and capital account restrictions is weakly statistically significant, implying a high degree on those restrictions impedes FDI flows between countries. Similarly, the measure of personal contact has a positive sign and is statistically significant. The sign on political globalization is negative.

In Regression 4, we applied country-pair fixed effects in Equation 2. All the variables are similar to Regression 3. We find all macroeconomic variables of our interest, such as market size, growths, and bilateral exchange rate, to be significant with correct sign. The results are superior to Regression 2 where we left out the KOF sub-indices. Furthermore, level of trade and capital restrictions are statistically significant with correct sign.

\section{Concluding Remarks}

This paper has investigated trends, patterns and drivers of intra-Asian FDI flows as well as examined the main drivers of FDI flows. While developing Asian countries will remain important recipients of FDI flows, many Asian firms are consciously attempting to invest overseas for a number of reasons. Indeed, many Chinese companies have made headlines as they have been on a hectic buying spree over the last few years, spurred by 
the government's desire to build "national champions" and as a means of ensuring energy security. More generally, however, overseas acquisitions undertaken by Asian companies recently have been aimed at buying brand names, acquire technology, processes, management know-how and marketing and distribution networks and to solidify existing markets or seek new ones. Such market-seeking investments can be expected to grow in importance as Asian companies are beginning to face intense foreign competition at home and are looking to expand overseas market shares while leveraging their latecomer advantages to catch up with their developed country competitors. Our empirical analysis using panel data involving 15 developing Asian countries for the period 1990 to 2004 indicates that economic factors such as market size, economic openness, close distance and language similarity are among the reasons that have promoted intra-Asian FDI flows.

While the governments in the NIEs have long encouraged their firms to invest abroad, especially in the rest of Asia, other Asian governments have jumped on the bandwagon as well. Most notably, the Chinese and Indian governments have taken a very positive attitude towards outward FDI and have been taken notable steps to liberalize capital account transactions, foreign ownership policies and foreign exchange policies and related rules as a means of promoting such outward investments. Bilateral and regional trade and investment agreements within the region will facilitate the crossborder flow of FDI. In turn, intensified intra-Asian FDI flows will help promote closer de facto regional integration. 


\section{Box 1: Inward versus Outward FDI Flows in UNCTAD data}

UNCTAD data on FDI is a compilation of FDI data reported by member country authorities and other multilateral agencies. Data from some countries, especially developing ones, still deviate one way or another from the recommendation of the IMF and OECD in their collection, definition and reporting of FDI. For example, some countries deviate from the suggested 10 percent threshold value for foreign equity ownership, and some do not report short-term loans and trade credits (UNCTAD, World Investment Report, 2005). These different reporting practices of FDI data create bilateral discrepancies between FDI flows reported by home and host countries. And, the differences can be quite large. For example, data on FDI flows to China as reported by the Chinese authorities and by the investing countries' authorities differ by roughly US\$ 30 billion in 2001, US\$ 8 billion in 2001, and US\$ 2 billion in 2002. According to UNCTAD, different methods of data collection by host and home countries, different data coverage of FDI (i.e. not all countries used equity capital, intra-company loans and reinvested earnings), different time periods used for recording FDI transactions, and different treatment of round trip investments are some of the causes. To complicate things even more, some countries FDI data show structural breakdown in their series due to change of policy or the appreciation of US dollar.

\section{Box 2. KOF Index of Globalization}

The index was introduced in 2002 and covers the economic, social, and political dimension of globalization by KOF (Swiss Institute for Business Cycle Research). The index defines globalization to be the process of creating networks of connections among actors at multi-continental distances, mediated through a variety of flows including people, information, and ideas, capital and goods.

More specifically, the three dimensions of the KOF index are defined as:

1. Economic globalization characterized as long distance flows of goods, capital and services as well as information and perceptions that accompany market exchanges. It has two sub-indices that include individual components suggested as proxies for globalization in the previous literature:

1.1. Actual flows. It includes actual economic flows that are used as measures of globalization, e.g. trade, FDI, and portfolio investments. The sources of data are World Bank (for trade), UNCTAD (for FDI stocks data), and IMF (for portfolio investment).

1.2. Restrictions. It refers to restrictions on trade and capital using hidden import barriers, mean tariffs, taxes on international trade, and an index of capital controls. The source of data is Gwartney and Lawson (2006). ${ }^{26}$

2. Social globalization is classified into three categories:

2.1. Personal contacts capture direct interaction among people living in different

${ }^{26}$ The source for Gwartney and Lawson (2006) index on restrictions on capital account is IMF's Annual Report on Exchange Arrangements and Exchange Restrictions. Mean tariff in their data originate from various sources. Original source for hidden import barrier is World Economic Forum's Global Competitiveness Report. 
countries. The sub-index includes data on international telecom traffic (outgoing traffic in minutes per subscriber); the degree of tourism (incoming and outgoing) that the destination country's population is exposed; government and workers' transfers received and paid; stock of foreign population; and, the number of international letters sent and received. The sources of data are World Bank's World Development Indicator database, and Universal Postal Union's Postal Statistics Database.

2.2. Information flows measure the potential flow of ideas and images. The sub-index consists of data on number of internet hosts and users, cable television subscribers, number of radios (all per 1000 people), and international newspapers traded (in percent of GDP). The sources of data are International Telecommunications Union's Yearbook of Statistics and its World Telecommunication Indicators database and World Bank's World Development Indicators database.

2.3. Cultural proximity captures the degree of cultural closeness between countries. This index is the most difficult to grasp because the available data are mostly biased towards the trend setter in much of the global socio-cultural realm-United States. The sub-index includes data on percentage of imported and exported books relative to GDP, number of McDonald's restaurants in a country.

3. Political globalization measures the degree to which a country is politically close to other country or involved in world politics. The sources of data are number of embassies and high commissions in a country, the number of multilateral organizations to which the country is a member, and the number of UN peace missions a country has participated.

Each of the variables introduced above is transformed to an index on a scale of 1 (low degree of globalization) to 100 (high degree of globalization). The data is transformed according to the percentiles of the original distribution. The weights for calculating the sub-indices are determined using principal components analysis for the entire sample of countries and years.

All variables are linearly interpolated before applying the weighting procedure when calculating the indices. Missing values at the border of the sample are substituted by the latest data available. When data are missing over the entire sample period, the weights are readjusted to correct it.

Given the KOF Index's wide scope of coverage of globalization, there have been a good number of empirical studies that employ it. ${ }^{27}$ The empirical studies have also become more varied as the index makes it possible for researchers to study links of globalization to other area that were difficult to examine, such as the impact of globalization to institutions.

\footnotetext{
${ }^{27}$ According to KOF's website, there are currently 26 empirical studies that have used the index.
} 


\section{Bibliography}

Accenture (2005). China Spreads its Wings - Chinese Companies go Global, Accenture.

Aguiar, M., A. Bhattacharya, T. Bradtke, P. Cotte, S. Dertnig, M. Meyer, D.C. Michael and H. Sirkin (2006). The New Global Challengers: How 100 Top Companies from Rapidly Developing Economies Are Changing the World, The Boston Consulting Group, May 25.

Aykut, D. and A. Goldstein (2006). "Developing Country Multinationals: South-South Investment Comes of Age," mimeo (undated).

Aykut, D. and D. Ratha (2004). "South-South FDI Flows: How Big are They?," Transnational Corporations, 13, pp.149-177.

Boston, Consulting Group (BCG) (2006). The New Global Challengers: How 100 Companies from Rapidly Developing Economies are Changing the World, The Boston Consulting Group, May.

Chantasasawat B., Fung K.C., lizaka H. and A.K.F. Siu (2004). "Foreign Direct Investment in China and East Asia," HIEBS Working Paper No.1135. Hong Kong.

Chen, E.K.Y. and P. Lin (2006). "Mainland China and Hong Kong Emerging TNCs from East Asia," Working Paper No.WP31, East Asian Bureau of Economic Research, Australia National University.

Duce, M. (2003). "Definitions of Foreign Direct Investment (FDI): A Methodological Note," Banco de Espana, mimeo (July).

Engardio, P. with M. Arndt and G. Smith (2006). "Emerging Giants," Business Week, July 31.

Frankel, J. and S.J. Wei, (1996). "ASEAN in a Regional Perspective," Working Paper No. PB96-02, Center for Pacific Basin Monetary and Economic Studies, Federal Reserve Bank of San Francisco, (November).

Gammeltoft, P. (2006). "Multinationals from the South: Outward FDI from the BRICs Countries," mimeo (September).

Gast, M. (2005). "Determinants of Foreign Direct Investment of OECD Countries 19912001," Discussion papers No.27, Zentrum für Internationale Entwicklungs-und Umweltforschung.

http://geb.uni-giessen.de/geb/volltexte/2005/2396/pdf/ZeuDiscPap27.pdf

Giridharadas, A. and S. Rai (2006). "Out of India: A "Third Wave of Globalization' Emerges," International Herald Tribune, October 17.

Globerman, S. and D. Shapiro (2005). "Assessing International Mergers and Acquisitions as a Mode of Foreign Direct Investment," in L. Eden and W. Dobson (eds.), Governance, Multinationals and Growth, London: Edwin Elgar, pp.68-99.

Gopinath, S. (2007). "Overseas Investments by Indian Companies: Evolution of Policy and Trends," keynote address at the International Conference on Indian Cross-border Presence/Acquisitions (Mumbai, January 19). 
Gwartney, J. and R. Lawson with W. Easterly (2006). Economic Freedom of the World: 2006 Annual Report.

Hiratsuka, (2006). "Outward FDI from ASEAN and Intraregional FDI in ASEAN: Trends and Drivers," ASEAN-UNCTAD Annual Seminar on Key Issues of FDI: Outward FDI from Asia Session 1, UNCTAD and ASEAN.

Hejazi, Walid (2005). "Are Regional Concentrations of OECD Exports and Outward FDI Consistent with Gravity," Atlantic Economic Journal, 33, 423-436.

International Monetary Fund (IMF) (2003). Foreign Direct Investment Statistics: How Countries Measure FDI 2001, IMF: Washington, DC.

Kharas, H., R.S. Rajan and E. Vostroknutova (2006). "Finance," in H. Kharas and I. Gill (eds.), An East Asian Renaissance: Ideas for Competitive Growth, World Bank: Washington, DC.

KOF-Index website http://globalization.kof.ethz.ch/.

Kwan, N. and F. Cheung (2006). "Asia Focus: Intra-Asia Investment Reinforces Integration," Standard Chartered, June 21.

Lee, Chang-Soo (2005). "Korea's FDI Outflows: Choice of Locations and Effect on Trade." Working Paper 02-07, Korea Institute for International Economic Policy (KIEP).

Lipsey, R.E. (1999). "The Location and Characteristics of U.S. Affiliates in Asia," Working Paper No.6876, NBER.

Mody, A. and S. Negishi (2001). "The Role of Cross-Border Mergers and Acquisitions in Asian Restructuring," in S. Claessens, S. Djankov, and A. Mody, in Resolution of Financial Distress, World Bank Institute, The World Bank, Washington DC.

Pardhan, J.P. (2005). "Outward Foreign Direct Investment from India: Recent Trends and Patterns," Working Paper No.153, Gujarat Institute of Development Research.

Rajan, R.S. (2005). "Financing Development in the Asia-Pacific Region: Trends and Linkages", The Role of Trade and Investment Policies in the Implementation of the Monterrey Consensus: Regional Perspectives, Studies in Trade and Investment No.55, pp.21-65.

Rajan, R.S. and S. Rongala (2007). Asian Economic Policy Issues: A Contemporary Perspective, World Scientific, forthcoming.

Razin, A., Y. Rubinstein and E. Sadka (2003). "Which Countries Export FDI, and How Much?", Working Paper No.10145, NBER.

Sauvant, K.P. (2005), "New Sources of FDI: The BRICs," The Journal of World Investment and Trade, 6, pp.639-711.

The Economist (2006). “The Dragon Tuck in,” June 30.

Tucker, S. and J. Leahy (2006). "Corporate India is Finding Confidence to Go Global," Financial Times, October 4. 
United Nations (2006). World Investment Report 2006, UN: New York and Geneva.

World Bank (2006). Global Development Finance, Oxford University Press: New York, Chapter 4.

Wu, F. (2005). "The Globalization of Corporate China," NBR Analysis, 16, The National Bureau of Asian Research, Seattle. 
Table 1: Growing Importance of South-South FDI, 1995-2003 (US\$ billions)

\begin{tabular}{lrrrrrr}
\hline & 1995 & 1999 & 2000 & 2001 & 2002 & $2003 \mathrm{e}$ \\
\hline Total inflows (1) & 90.3 & 163.5 & 154.7 & 159.3 & 135.3 & 129.6 \\
$\quad$ From high-income OECD (2) & 48.1 & 95.4 & 93.7 & 84.8 & 55.1 & 59.4 \\
$\quad$ From high-income non-OECD (3) & 28.2 & 35.0 & 22.7 & 24.8 & 27.2 & 22.8 \\
South-South FDI (1)-(2)-(3) & 14.0 & 33.1 & 38.3 & 49.7 & 53.0 & 47.4 \\
$\quad$ South-South FDI (percent) & 15.5 & 20.2 & 24.8 & 31.2 & 39.2 & 36.6 \\
\hline
\end{tabular}

Notes: The South-South estimates are based on 35 countries that account for 85 percent of total FDI flows to developing countries. The estimates are based on the World Bank's classification of developing countries. Source: World Bank (2006). 
Table 2: Distribution of FDI by Region and Selected Countries, 1980-2005

(In percent)

\begin{tabular}{|c|c|c|c|c|c|c|c|c|}
\hline \multirow[t]{2}{*}{ Region } & \multicolumn{4}{|c|}{ Inward Stock } & \multicolumn{4}{|c|}{ Outward Stock } \\
\hline & 1980 & 1990 & 2000 & 2005 & 1980 & 1990 & 2000 & 2005 \\
\hline Developed Economies & 75.6 & 79.3 & 68.5 & 70.3 & 87.3 & 91.7 & 86.2 & 86.9 \\
\hline European Union & 42.5 & 42.9 & 37.6 & 44.4 & 37.2 & 45.2 & 47.1 & 51.3 \\
\hline Japan & 0.6 & 0.6 & 0.9 & 1.0 & 3.4 & 11.2 & 4.3 & 3.6 \\
\hline United States & 14.8 & 22.1 & 21.7 & 16.0 & 37.7 & 24.0 & 20.3 & 19.2 \\
\hline Developing Economies & 24.4 & 20.7 & 30.3 & 27.2 & 12.7 & 8.3 & 13.5 & 11.9 \\
\hline Africa & 6.9 & 3.3 & 2.6 & 2.6 & 1.3 & 1.1 & 0.7 & 0.5 \\
\hline Latin America and the Caribbean & 7.1 & 6.6 & 9.3 & 9.3 & 6.5 & 3.4 & 3.3 & 3.2 \\
\hline Asia & 10.5 & 10.8 & 18.4 & 15.4 & 2.9 & 3.8 & 9.5 & 8.2 \\
\hline West Asia & 1.4 & 2.2 & 1.1 & 1.5 & 0.3 & 0.4 & 0.2 & 0.3 \\
\hline South, East and South-East Asia & 8.8 & 8.5 & 17.2 & 13.8 & 2.5 & 3.4 & 9.3 & 7.6 \\
\hline South-East Europe and CIS & - & 0.01 & 1.2 & 2.5 & - & 0.01 & 0.3 & 1.2 \\
\hline World & 100.0 & 100.0 & 100.0 & 100.0 & 100.0 & 100.0 & 100.0 & 100.0 \\
\hline \multirow[t]{2}{*}{ Region } & \multicolumn{4}{|c|}{ Inflow } & \multicolumn{4}{|c|}{ Outflow } \\
\hline & 1978-1980 & 1988-1990 & $1998-2000$ & 2003-2005 & $1978-1980$ & 1988-1990 & 1998-2000 & 2003-2005 \\
\hline Developed Economies & 79.7 & 82.5 & 77.3 & 59.4 & 97.0 & 93.1 & 90.4 & 85.8 \\
\hline European Union & 39.1 & 40.3 & 46.0 & 40.7 & 44.8 & 50.6 & 64.4 & 54.6 \\
\hline Japan & 0.4 & 0.04 & 0.8 & 0.8 & 4.9 & 19.7 & 2.6 & 4.9 \\
\hline United States & 23.8 & 31.5 & 24.0 & 12.5 & 39.7 & 13.6 & 15.9 & 15.7 \\
\hline Developing Economies & 20.3 & 17.5 & 21.7 & 35.9 & 3.0 & 6.9 & 9.4 & 12.3 \\
\hline Africa & 2.0 & 1.9 & 1.0 & 3.0 & 1.0 & 0.4 & 0.2 & 0.2 \\
\hline Latin America and the Caribbean & 13.0 & 5.0 & 9.7 & 11.5 & 1.1 & 1.0 & 4.1 & 3.5 \\
\hline Asia & 5.3 & 10.5 & 11.0 & 21.4 & 0.9 & 5.6 & 5.1 & 8.6 \\
\hline West Asia & -1.6 & 0.3 & 0.3 & 3.0 & 0.3 & 0.5 & 0.1 & 1.0 \\
\hline South, East and South-East Asia & 6.7 & 10.0 & 10.7 & 18.4 & 0.6 & 5.1 & 5.0 & 7.7 \\
\hline South-East Europe and CIS & 0.0 & 0.02 & 0.9 & 4.7 & - & 0.01 & 0.2 & 1.8 \\
\hline World & 100.0 & 100.0 & 99.9 & 100.0 & 100.0 & 100.0 & 100.0 & 100.0 \\
\hline
\end{tabular}

Source: UNCTAD FDI/TNC database. 
Table 3. FDI Inflows and Outflows of Selected Asian Countries

\begin{tabular}{|c|c|c|c|c|c|c|c|c|c|c|c|}
\hline \multicolumn{12}{|c|}{ (In billions of U.S. dollars) } \\
\hline Country & $1990-1996$ & $1997-2005$ & 1997 & 1998 & 1999 & 2000 & 2001 & 2002 & 2003 & 2004 & 2005 \\
\hline World & 248.30 & 816.23 & 489.71 & 712.03 & $1,099.92$ & $1,409.57$ & 832.25 & 617.73 & 557.87 & 710.75 & 916.28 \\
\hline Asia (excluding Japan) & 51.31 & 114.56 & 100.40 & 91.06 & 108.66 & 143.83 & 103.99 & 88.61 & 93.72 & 137.02 & 163.72 \\
\hline New Industrial Asia & 9.18 & 21.55 & 18.64 & 12.60 & 29.13 & 30.06 & 23.62 & 11.83 & 14.72 & 24.45 & 28.91 \\
\hline Korea & 2.34 & 5.75 & 2.64 & 5.07 & 9.63 & 8.65 & 3.87 & 3.04 & 3.89 & 7.73 & 7.20 \\
\hline Singapore & 5.89 & 13.60 & 13.75 & 7.31 & 16.58 & 16.48 & 15.65 & 7.34 & 10.38 & 14.82 & 20.08 \\
\hline Taiwan POC & 0.95 & 2.21 & 2.25 & 0.22 & 2.93 & 4.93 & 4.11 & 1.45 & 0.45 & 1.90 & 1.63 \\
\hline China & 25.00 & 76.40 & 56.63 & 60.23 & 64.90 & 102.64 & 70.65 & 62.42 & 67.13 & 94.66 & 108.30 \\
\hline China: Mainland & 20.43 & 50.88 & 45.26 & 45.46 & 40.32 & 40.71 & 46.88 & 52.74 & 53.51 & 60.63 & 72.41 \\
\hline Hong Kong SAR & 4.57 & 25.52 & 11.37 & 14.76 & 24.58 & 61.92 & 23.78 & 9.68 & 13.62 & 34.03 & 35.90 \\
\hline ASEAN-4 & 8.48 & 8.50 & 16.13 & 11.72 & 9.37 & 4.83 & 1.66 & 5.84 & 4.32 & 8.62 & 14.05 \\
\hline Indonesia & 2.71 & 0.19 & 4.68 & -0.24 & -1.87 & -4.55 & -2.98 & 0.15 & -0.60 & 1.90 & 5.26 \\
\hline Malaysia & 3.62 & 3.50 & 6.32 & 2.71 & 3.90 & 3.79 & 0.55 & 3.20 & 2.47 & 4.62 & 3.97 \\
\hline Philippines & 0.92 & 1.17 & 1.25 & 1.75 & 1.25 & 2.24 & 0.20 & 1.54 & 0.49 & 0.69 & 1.13 \\
\hline Thailand & 1.23 & 3.63 & 3.88 & 7.49 & 6.09 & 3.35 & 3.89 & 0.95 & 1.95 & 1.41 & 3.69 \\
\hline South Asia & 2.44 & 5.90 & 5.34 & 3.87 & 3.21 & 4.65 & 6.38 & 6.97 & 5.70 & 7.29 & 9.75 \\
\hline India & 1.38 & 4.42 & 3.62 & 2.63 & 2.17 & 3.59 & 5.47 & 5.63 & 4.59 & 5.47 & 6.60 \\
\hline Pakistan & 0.34 & 0.79 & 0.71 & 0.51 & 0.53 & 0.31 & 0.38 & 0.82 & 0.53 & 1.12 & 2.18 \\
\hline Sri Lanka & 0.09 & 0.23 & 0.43 & 0.15 & 0.20 & 0.17 & 0.17 & 0.20 & 0.23 & 0.23 & 0.27 \\
\hline Bangladesh & 0.63 & 0.47 & 0.58 & 0.58 & 0.31 & 0.58 & 0.35 & 0.33 & 0.35 & 0.46 & 0.69 \\
\hline \multicolumn{12}{|l|}{ Outflows } \\
\hline World & 269.72 & 776.31 & 483.14 & 694.40 & $1,108.17$ & $1,244.47$ & 764.20 & 539.54 & 561.10 & 813.07 & 778.73 \\
\hline Asia (excluding Japan) & 29.14 & 50.05 & 51.23 & 31.69 & 39.87 & 80.69 & 48.35 & 33.76 & 21.15 & 76.11 & 67.63 \\
\hline New Industrial Asia & 8.92 & 16.87 & 20.60 & 10.74 & 16.62 & 17.62 & 28.07 & 9.79 & 12.25 & 20.32 & 15.86 \\
\hline Korea & 2.25 & 3.98 & 4.45 & 4.74 & 4.20 & 5.00 & 2.42 & 2.62 & 3.43 & 4.66 & 4.31 \\
\hline Singapore & 3.62 & 7.40 & 10.90 & 2.16 & 8.00 & 5.92 & 20.17 & 2.29 & 3.14 & 8.51 & 5.52 \\
\hline Taiwan POC & 3.05 & 5.49 & 5.24 & 3.84 & 4.42 & 6.70 & 5.48 & 4.89 & 5.68 & 7.15 & 6.03 \\
\hline China & 17.21 & 29.22 & 26.97 & 19.62 & 21.14 & 60.27 & 18.23 & 19.98 & 5.34 & 47.52 & 43.87 \\
\hline China: Mainland & 2.32 & 3.36 & 2.56 & 2.63 & 1.77 & 0.92 & 6.89 & 2.52 & -0.15 & 1.81 & 11.31 \\
\hline Hong Kong SAR & 14.89 & 25.85 & 24.41 & 16.98 & 19.37 & 59.35 & 11.35 & 17.46 & 5.49 & 45.72 & 32.56 \\
\hline$A S E A N-4$ & 2.94 & 2.96 & 3.57 & 1.20 & 1.98 & 2.28 & 0.60 & 2.26 & 2.17 & 6.17 & 6.44 \\
\hline Indonecia & 091 & 0.80 & 0.18 & 0.04 & 0.07 & 0.15 & 0.13 & 0.18 & 0.01 & 3.41 & 3.07 \\
\hline Malaysia & 1.44 & 1.73 & 2.68 & 0.86 & 1.42 & 2.03 & 0.27 & 1.90 & 1.37 & 2.06 & 2.97 \\
\hline Philippines & 0.16 & 0.17 & 0.14 & 0.16 & 0.13 & 0.13 & -0.14 & 0.07 & 0.30 & 0.58 & 0.16 \\
\hline Thailand & 0.43 & 0.26 & 0.58 & 0.13 & 0.35 & -0.02 & 0.35 & 0.11 & 0.49 & 0.13 & 0.25 \\
\hline South Asia & 0.07 & 1.00 & 0.10 & 0.11 & 0.13 & 0.52 & 1.45 & 1.72 & 1.38 & 2.09 & 1.46 \\
\hline India & 0.07 & 0.95 & 0.11 & 0.05 & 0.08 & 0.51 & 1.40 & 1.68 & 1.33 & 2.02 & 1.36 \\
\hline Pakistan & 0.00 & 0.03 & -0.02 & 0.05 & 0.02 & 0.01 & 0.03 & 0.03 & 0.02 & 0.06 & 0.04 \\
\hline Sri Lanka & 0.00 & 0.01 & 0.01 & 0.01 & 0.02 & 0.00 & 0.00 & 0.01 & 0.03 & 0.01 & 0.04 \\
\hline Bangladesh & 0.00 & 0.01 & 0.00 & 0.00 & 0.00 & 0.00 & 0.02 & 0.00 & 0.01 & 0.01 & 0.01 \\
\hline
\end{tabular}


Table 4. Correlations Between Inflows and Outflows to and from Asia

Country

1990-96 1997-05

$\begin{array}{lrr}\text { Asia } & 1.0 & 0.9 \\ \text { New Industrial Asia } & 0.9 & 0.5 \\ \text { Korea } & -0.4 & 0.6 \\ \text { Singapore } & 0.9 & 0.5 \\ \text { Taiwan POC } & 0.1 & 0.4 \\ \text { China } & 1.0 & 0.8 \\ \text { China: Mainland } & 0.2 & 0.6 \\ \text { Hong Kong SAR } & 0.9 & 0.9 \\ \text { ASEAN-4 } & 0.8 & 0.5 \\ \text { Indonesia } & 0.1 & 0.6 \\ \text { Malaysia } & 0.9 & 0.8 \\ \text { Philippines } & 0.7 & -0.1 \\ \text { Thailand } & 0.8 & 0.1 \\ \text { South Asia } & 0.4 & 0.8 \\ \text { India } & 0.8 & 0.9 \\ \text { Pakistan } & 0.4 & 0.4 \\ \text { Sri Lanka } & 0.8 & 0.1 \\ \text { Bangladesh } & -0.4 & -0.1\end{array}$

Sources: Authors calculation 
Table 5: Top 20 Developing and Transition Economies in Terms of Stocks of Outward FDI, 1980, 1990, 2000 and 2005 (US\$ Millions)

\begin{tabular}{|c|c|c|c|c|c|c|c|c|c|c|c|}
\hline Rank & Economy & 1980 & Rank & Economy & 1990 & Rank & Economy & 2000 & Rank & Economy & 2005 \\
\hline 1 & Brazil & 38,545 & 1 & Brazil & 41,044 & 1 & Hong Kong SAR & 388,380 & 1 & $\begin{array}{l}\text { Hong Kong SAR } \\
\text { British Virgin }\end{array}$ & 470,458 \\
\hline 2 & Taiwan & 13,009 & 2 & Taiwan & 30,356 & 2 & Taiwan & 66,655 & 2 & Islands & 123,167 \\
\hline 3 & Argentina & 5,970 & 3 & South Africa & 15,004 & 3 & British Virgin Islands & 64,483 & 3 & Russian Federation & 120,417 \\
\hline 4 & South Africa & 5,541 & 4 & Hong Kong SAR & 11,920 & 4 & Singapore & 56,766 & 4 & Singapore & 110,932 \\
\hline 5 & Mexico & 1,632 & 5 & Singapore & 7,808 & 5 & Brazil & 51,946 & 5 & Taiwan & 97,293 \\
\hline 6 & $\begin{array}{l}\text { Kuwait } \\
\text { Libyan Arab }\end{array}$ & 1,046 & 6 & Argentina & 6,057 & 6 & South Africa & 32,319 & 6 & Brazil & 71,556 \\
\hline 7 & Jamahiriya & 870 & 7 & China & 4,455 & 7 & China & 27,768 & 7 & China & 46,311 \\
\hline 8 & Panama & 811 & 8 & Panama & 4,188 & 8 & South Korea & 26,833 & 8 & Malaysia & 44,480 \\
\hline 9 & Bermuda & 727 & 9 & Kuwait & 3,662 & 9 & Malaysia & 22,874 & 9 & South Africa & 38,503 \\
\hline 10 & Singapore & 623 & 10 & Mexico & 2,672 & 10 & Argentina & 21,141 & 10 & South Korea & 36,478 \\
\hline 11 & Bahrain & 598 & 11 & Malaysia & 2,671 & 11 & Cayman Islands & 20,553 & 11 & Cayman Islands & 33,747 \\
\hline 12 & Botswana & 440 & 12 & South Korea & 2,301 & 12 & Russian Federation & 20,141 & 12 & Mexico & 28,040 \\
\hline 13 & Bahamas & 285 & 13 & Saudi Arabia & 1,873 & 13 & Bermuda & 14,942 & 13 & Argentina & 22,633 \\
\hline 14 & Saudi Arabia & 239 & 14 & $\begin{array}{l}\text { Bermuda } \\
\text { Libyan Arab }\end{array}$ & 1,550 & 14 & Chile & 11,154 & 14 & Chile & 21,286 \\
\hline 15 & Malaysia & 197 & 15 & Jamahiriya & 1,321 & 15 & Mexico & 8,273 & 15 & Indonesia & 13,735 \\
\hline 16 & Uruguay & 171 & 16 & Venezuela & 1,221 & 16 & Venezuela & 7,676 & 16 & Panama & 12,891 \\
\hline 17 & $\begin{array}{l}\text { Philippines } \\
\text { Hong Kong }\end{array}$ & 171 & 17 & Nigeria & 1,207 & 17 & Indonesia & 6,940 & 17 & $\begin{array}{l}\text { Venezuela } \\
\text { United Arab }\end{array}$ & 10,665 \\
\hline 18 & SAR & 148 & 18 & Turkey & 1,157 & 18 & Nigeria & 4,132 & 18 & Emirates & 10,087 \\
\hline 19 & Colombia & 136 & 19 & British Virgin Islands & 875 & 19 & Panama & 4,004 & 19 & India & 9,569 \\
\hline 20 & Paraguay & 129 & 20 & Bahrain & 719 & 20 & Turkey & 3,668 & 20 & Colombia & 8,876 \\
\hline 25 & India & 78 & 39 & India & 124 & 23 & Thailand & 2,203 & 26 & Thailand & 3,947 \\
\hline 39 & Thailand & 13 & 26 & Thailand & 418 & 25 & India & 1,859 & 31 & Philippines & 2,039 \\
\hline 45 & Indonesia & 6 & 43 & Indonesia & 86 & 28 & Philippines & 1,597 & & & \\
\hline
\end{tabular}

Source: UNCTAD, Foreign Direct Investment (WIR 2006 data) www.unctad.org/fdistatistics. 
Table 6: Basic Facts about the outward FDI stock of Selected Asian Economies, 2005 or latest year available

\begin{tabular}{|c|c|c|c|c|c|c|}
\hline Country & $\begin{array}{c}\text { Outward } \\
\text { stock } \\
\text { (millions US\$) } \\
\end{array}$ & $\begin{array}{l}\text { Outward } \\
\text { stock per } \\
\text { capita } \\
\text { (US\$) }\end{array}$ & $\begin{array}{l}\text { Outward } \\
\text { Stock as } \\
\text { share of } \\
\text { GDP (\%) }\end{array}$ & $\begin{array}{c}\text { Outward FDI } \\
\text { and a share } \\
\text { of Gross } \\
\text { capital } \\
\text { formation (\%) }\end{array}$ & Top five recipients & Top three industries \\
\hline Hong Kong & 470,458 & 66,818 & 265 & 108.8 & $\begin{array}{l}\text { British Virgin Islands. China, } \\
\text { Bermuda, United Kingdom, Japan } \\
\text { a }\end{array}$ & $\begin{array}{l}\text { Business activities, trade, } \\
\text { transport, storage and } \\
\text { communications }^{a}\end{array}$ \\
\hline Singapore & 110,932 & 25,646 & 94 & 27,2 & $\begin{array}{l}\text { British Virgin Islands, China, } \\
\text { Malaysia, Bermuda, Hong Kong }{ }^{\text {b }}\end{array}$ & $\begin{array}{l}\text { Finance, transport; storage and } \\
\text { communications, trade }\end{array}$ \\
\hline China & 46,311 & 35 & 2 & 0.8 & $\begin{array}{l}\text { Hong Kong, Cayman Islands, } \\
\text { Virgin Islands, United States, } \\
\text { Russian Federation }{ }^{\text {a }}\end{array}$ & $\begin{array}{l}\text { Business activities, trade, mining, } \\
\text { quarrying and petroleum a }\end{array}$ \\
\hline South Korea & 36,478 & 763 & 5 & 2.1 & $\begin{array}{l}\text { United States, China, } \\
\text { Netherlands, Bermuda, Hong } \\
\text { Kong }^{c}\end{array}$ & $\begin{array}{l}\text { Trade; electronic and electrical } \\
\text { equipment; textiles and clothing }\end{array}$ \\
\hline India & 9,569 & 9 & 1 & 0.9 & & \\
\hline Indonesia & 13,735 & 62 & 5 & 5.6 & & \\
\hline Philippines & 2,039 & 25 & 2 & 2.6 & & \\
\hline $\begin{array}{l}\text { Taiwan, } \\
\text { China }\end{array}$ & 97,293 & 4,230 & 28 & 9.5 & & \\
\hline Thailand & 3,947 & 61 & 2 & 0.4 & & \\
\hline
\end{tabular}

Source: UNCTAD FDI/TNC database (www.unctad.org.fdistatistics)

Notes: a) 2004, b) 2003, c) 2002. 
Table 7. Average of Intra-Asian Bilateral FDI Outward Flows

(In millions of U.S. dollars, unless otherwise noted)

\begin{tabular}{|c|c|c|c|c|c|c|}
\hline & \multicolumn{6}{|c|}{ Host region 1/ } \\
\hline & \multicolumn{3}{|c|}{$(1997-00)$} & \multicolumn{3}{|c|}{$(2001-05)$} \\
\hline & Asia 2/ & $\begin{array}{l}\text { In percent } \\
\text { of Asia }\end{array}$ & $\begin{array}{c}\text { In percent } \\
\text { of World }\end{array}$ & Asia 2/ & $\begin{array}{c}\text { In percent } \\
\text { of Asia }\end{array}$ & $\begin{array}{c}\text { In percent } \\
\text { of World }\end{array}$ \\
\hline \multicolumn{7}{|l|}{ Donor countries } \\
\hline Bangladesh & 0.2 & 0.0 & 0.0 & 0.5 & 0.0 & 0.0 \\
\hline China & $7,356.8$ & 15.7 & 0.8 & $5,646.9$ & 13.5 & 0.8 \\
\hline Hong Kong SAR & $18,869.8$ & 40.2 & 2.0 & $18,652.4$ & 44.6 & 2.6 \\
\hline India & 43.9 & 0.1 & 0.0 & 34.9 & 0.1 & 0.0 \\
\hline Indonesia & 254.9 & 0.5 & 0.0 & 190.7 & 0.5 & 0.0 \\
\hline Korea & 656.4 & 1.4 & 0.1 & 274.1 & 0.7 & 0.0 \\
\hline Malaysia & 376.6 & 0.8 & 0.0 & 433.1 & 1.0 & 0.1 \\
\hline Pakistan & 1.4 & 0.0 & 0.0 & 6.2 & 0.0 & 0.0 \\
\hline Philippines & 180.4 & 0.4 & 0.0 & 263.8 & 0.6 & 0.0 \\
\hline Singapore & $7,018.5$ & 14.9 & 0.8 & $5,188.5$ & 12.4 & 0.7 \\
\hline Sri Lanka & 2.7 & 0.0 & 0.0 & 0.2 & 0.0 & 0.0 \\
\hline Taiwan POC & $3,376.5$ & 7.2 & 0.4 & $4,016.6$ & 9.6 & 0.6 \\
\hline Thailand & 289.3 & 0.6 & 0.0 & 232.0 & 0.6 & 0.0 \\
\hline Developing A & $8,525.0$ & 18.1 & 0.9 & $6,846.1$ & 16.4 & 0.9 \\
\hline Asia 2/ & $46,996.1$ & 100.0 & 5.1 & $41,834.8$ & 100.0 & 5.8 \\
\hline
\end{tabular}

Source: UNCTAD FDI/TNC database.

1/ Asia data is based on FDI inflow data in host economy; world data is based on FDI outflow from donor economy.

2/ Asia consists of Bangladesh, Brunei Darussalam, Cambodia, China, Hong Kong SAR, India, Indonesia, Korea, Lao PDR, Malaysia, Myanmar, Pakistan, Philippines, Singapore,

Sri Lanka, Taiwan POC, Thailand, and Vietnam

3/ Developing Asia consists of Bangladesh, Cambodia, China, Hong Kong SAR, India, Indonesia, Lao PDR, Malaysia, Myanmar, Pakistan, Philippines, Sri Lanka,

Thailand, and Vietnam 
Table 8. Average Intra-Asian Bilateral FDI Outward Flows 1/

(In millions of U.S. dollars)

\begin{tabular}{|c|c|c|c|c|c|c|}
\hline & \multicolumn{6}{|c|}{ Host region } \\
\hline & \multicolumn{3}{|c|}{$(1997-00)$} & \multicolumn{3}{|c|}{$(2001-05)$} \\
\hline & $\begin{array}{c}\text { East Asia } \\
\text { 2/ }\end{array}$ & $\begin{array}{c}\text { South-East } \\
\text { Asia 3/ }\end{array}$ & $\begin{array}{c}\text { South Asia } \\
4 /\end{array}$ & $\begin{array}{c}\text { East Asia } \\
\text { 2/ }\end{array}$ & $\begin{array}{c}\text { South-East } \\
\text { Asia 3/ }\end{array}$ & South Asia \\
\hline \multicolumn{7}{|l|}{ Donor region } \\
\hline East Asia 2/ & $28,453.6$ & $1,604.2$ & 201.6 & $27,482.5$ & $1,028.7$ & 78.9 \\
\hline South-East Asia 3/ & $6,328.7$ & $1,748.2$ & 86.6 & $3,622.3$ & $2,623.4$ & 111.1 \\
\hline South Asia 4/ & 0.0 & 42.9 & 5.2 & 0.0 & 27.3 & 14.6 \\
\hline Rest of the world & $42,812.3$ & $21,340.5$ & $3,732.2$ & $46,489.8$ & $21,056.5$ & $3,821.0$ \\
\hline \multicolumn{7}{|c|}{$\begin{array}{l}\text { 1/ Based on FDI inflow data in host economy. } \\
\text { 2/ East Asia consists of China, Hong Kong SAR, Korea, Taiwan POC, and Macau SAR. } \\
\text { 3/ South-East Asia consists of Brunei Darussalam, Cambodia, Lao PDR, Malaysia, Myanmar, Singapore, Phillippines, } \\
\text { Thailand, and Vietnam. } \\
\text { 4/ South Asia consists of Bangladesh, India, Sri Lanka, and Pakistan. }\end{array}$} \\
\hline
\end{tabular}


Table 9. Top 30 Bilateral Flow

Between Asian Countries 1/

(In million of U.S. dollars)

\begin{tabular}{|c|c|c|c|c|c|}
\hline \multirow{2}{*}{$\begin{array}{l}\text { Donor } \\
\text { Hong Kong SAR }\end{array}$} & Host & $\begin{array}{r}\text { Ave } \\
(1997-00)\end{array}$ & $\begin{array}{l}\text { age } \\
(2001-05)\end{array}$ & $\begin{array}{c}\text { In percer } \\
(1997-00)\end{array}$ & $\begin{array}{l}\text { tt to Asia } \\
(2001-05)\end{array}$ \\
\hline & China & $17,750.8$ & $17,819.1$ & 37.8 & $\overline{42.6}$ \\
\hline China & Hong Kong SAR & $7,266.9$ & $5,459.4$ & 15.5 & 13.0 \\
\hline Taiwan POC & China & $2,774.8$ & $3,361.3$ & 5.9 & 8.0 \\
\hline Singapore & China & $2,706.3$ & $2,136.7$ & 5.8 & 5.1 \\
\hline Singapore & Thailand & 441.7 & $1,381.9$ & 0.9 & 3.3 \\
\hline Singapore & Malaysia & 844.1 & $1,133.8$ & 1.8 & 2.7 \\
\hline Taiwan POC & Hong Kong SAR & 268.9 & 446.6 & 0.6 & 1.1 \\
\hline Singapore & Hong Kong SAR & $2,835.3$ & 353.1 & 6.0 & 0.8 \\
\hline Malaysia & China & 290.8 & 316.7 & 0.6 & 0.8 \\
\hline Hong Kong SAR & Malaysia & 272.3 & 296.5 & 0.6 & 0.7 \\
\hline Philippines & China & 135.9 & 212.2 & 0.3 & 0.5 \\
\hline Thailand & China & 185.8 & 183.7 & 0.4 & 0.4 \\
\hline Hong Kong SAR & Thailand & 360.1 & 160.8 & 0.8 & 0.4 \\
\hline Hong Kong SAR & Macau & 0.0 & 158.0 & 0.0 & 0.4 \\
\hline Korea & Hong Kong SAR & 313.0 & 155.7 & 0.7 & 0.4 \\
\hline Malaysia & Hong Kong SAR & 62.0 & 147.2 & 0.1 & 0.4 \\
\hline Indonesia & China & 115.0 & 134.0 & 0.2 & 0.3 \\
\hline Hong Kong SAR & Myanmar & 0.0 & 132.0 & 0.0 & 0.3 \\
\hline Thailand & Hong Kong SAR & -3.1 & 110.7 & 0.0 & 0.3 \\
\hline China & Singapore & -17.3 & 99.9 & 0.0 & 0.2 \\
\hline Taiwan POC & Thailand & 130.8 & 96.1 & 0.3 & 0.2 \\
\hline Taiwan POC & Singapore & 96.0 & 87.9 & 0.2 & 0.2 \\
\hline Hong Kong SAR & Singapore & 250.1 & 81.9 & 0.5 & 0.2 \\
\hline Singapore & Philippines & 88.9 & 76.1 & 0.2 & 0.2 \\
\hline Singapore & India & 22.0 & 67.6 & 0.0 & 0.2 \\
\hline Hong Kong SAR & Philippines & 50.0 & 54.4 & 0.1 & 0.1 \\
\hline Hong Kong SAR & Korea & 79.2 & 51.5 & 0.2 & 0.1 \\
\hline Philippines & Thailand & 4.9 & 48.4 & 0.0 & 0.1 \\
\hline China & Cambodia & 18.3 & 33.4 & 0.0 & 0.1 \\
\hline Korea & Thailand & 24.5 & 32.4 & 0.1 & 0.1 \\
\hline
\end{tabular}

Source: UNCTAD FDI database

1/ Based on FDI inflow data in host economy. 
Table 10. The Determinants of Intra-Asia Bilateral FDI Outflows

\begin{tabular}{|c|c|c|c|c|}
\hline $\begin{array}{l}\text { Dependent variable: } \\
\text { Ln of bilateral FDI outflows }\end{array}$ & $\begin{array}{c}\text { Regression } \\
\text { (1) }\end{array}$ & $\begin{array}{c}\text { Regression } \\
\text { (2) }\end{array}$ & $\begin{array}{c}\text { Regression } \\
\text { (3) }\end{array}$ & $\begin{array}{c}\text { Regression } \\
\text { (4) }\end{array}$ \\
\hline$\overline{l n}$ In (GDP i * GDP j) & $\begin{array}{l}0.125^{\star \star} \\
(0.06)\end{array}$ & $\begin{array}{l}0.404 \\
(0.41)\end{array}$ & $\begin{array}{c}0.638^{* * *} \\
(0.09)\end{array}$ & $\begin{array}{l}0.958^{\star *} \\
(0.47)\end{array}$ \\
\hline In (Real GDP growth i * Real GDP growth j) & $\begin{array}{c}0.582^{* * *} \\
(0.11)\end{array}$ & $\begin{array}{l}0.211^{* *} \\
(0.08)\end{array}$ & $\begin{array}{c}0.331^{* * *} \\
(0.13)\end{array}$ & $\begin{array}{l}0.234^{* *} \\
(0.09)\end{array}$ \\
\hline Bilateral exchange rate & $\begin{array}{l}0.033^{*} \\
(0.02)\end{array}$ & $\begin{array}{l}-0.443^{\star *} \\
(0.19)\end{array}$ & $\begin{array}{l}-0.011 \\
(0.02)\end{array}$ & $\begin{array}{c}-0.609^{* * *} \\
(0.22)\end{array}$ \\
\hline common border & $\begin{array}{l}0.193 \\
(0.29)\end{array}$ & & $\begin{array}{c}1.218^{* * *} \\
(0.32)\end{array}$ & \\
\hline common languange & $\begin{array}{c}1.082^{* * *} \\
(0.19)\end{array}$ & & $\begin{array}{l}0.293 \\
(0.23)\end{array}$ & \\
\hline In distance & $\begin{array}{c}-0.521^{* * *} \\
(0.17)\end{array}$ & & $\begin{array}{l}-0.255 \\
(0.19)\end{array}$ & \\
\hline In (Restrictions i + Restictions j) & & & $\begin{array}{l}-1.558^{*} \\
(0.83)\end{array}$ & $\begin{array}{c}-3.179^{* * *} \\
(0.75)\end{array}$ \\
\hline In (Personal contacts $\mathrm{i}+$ Personal contacts $\mathrm{j}$ ) & & & $\begin{array}{c}1.866^{* * *} \\
(0.33)\end{array}$ & $\begin{array}{l}1.178 \\
(0.99)\end{array}$ \\
\hline In (Information flows $\mathrm{i}+$ Information flows $\mathrm{j}$ ) & & & $\begin{array}{l}0.16 \\
(0.60)\end{array}$ & $\begin{array}{l}0.352 \\
(0.64)\end{array}$ \\
\hline In (Cultural proximity i + Cultural proximity j) & & & $\begin{array}{c}1.206^{* * *} \\
(0.29)\end{array}$ & $\begin{array}{l}0.164 \\
(0.31)\end{array}$ \\
\hline In (Political globalization i + Political globalization j) & & & $\begin{array}{c}-1.734^{\star \star *} \\
(0.65)\end{array}$ & $\begin{array}{c}-1.939^{\star \star *} \\
(0.68)\end{array}$ \\
\hline Constant & $\begin{array}{l}0.842 \\
(3.22)\end{array}$ & $\begin{array}{r}-19.331 \\
(22.16)\end{array}$ & $\begin{array}{l}-27.275^{\star * \star} \\
-5.178\end{array}$ & $\begin{array}{l}-32.4 \\
-24.68\end{array}$ \\
\hline Observations & 1004 & 1004 & 854 & 854 \\
\hline R-squared & 0.12 & 0.09 & 0.24 & 0.13 \\
\hline Country Pair Dummies & No & Yes & No & Yes \\
\hline Year Dummies & Yes & Yes & Yes & Yes \\
\hline
\end{tabular}

Notes: Robust standard error in parentheses.

${ }^{*}$ significant at $10 \%$; ${ }^{* *}$ significant at $5 \%$; ${ }^{* *}$ significant at $1 \%$

Source: Authors calculation 
Table A1

Variables Source

FDI Outflows

UNCTAD FDI/TNC database

Real GDP, PPP

World Development Indicators, World Bank

Exchange rate

Distance

Index of Actual Capital Flows

World Economic Outlook, IMF

Index of Capital and Trade Restr

Index of Information Flows

CIPEE

KOF

KOF

KOF

Index of Personal Contacts

KOF

Index of Cultural Proximity

KOF

Index of Political Globalization

KOF

Common colony

Common official language

CIPEE

Share of agriculture

CIPEE

Land border

World Development Indicators, World Bank CIPEE 
Table A2. Countries Included in the Dataset

\begin{tabular}{lll}
\multicolumn{2}{c}{ Source countries } & in \\
Bangladesh & Korea & Sri Lanka \\
China & Malaysia & Taiwan POC \\
Hong Kong SAR & Pakistan & Thailand \\
India & Philippines & Vietnam \\
Indonesia & Singapore & \\
Destination countries & \\
Bangladesh & Malaysia & \\
China & Pakistan & \\
Hong Kong SAR & Philippines & \\
India & Singapore & \\
Korea & Thailand &
\end{tabular}

